\title{
Agronomic traits and chemical composition of forage sorghum plants fertilized with poultry litter and fermentative profile of silages
}

\author{
Nagnaldo T. Lucena ${ }^{1}$, Edson M. Santos ${ }^{1}$, Juliana S. Oliveira ${ }^{1}$, Alexandre F. Perazzo ${ }^{2}$, \\ Gabriel F.L. Cruz ${ }^{1 *}$, Danillo M. Pereira ${ }^{1}$, Gildênia A. Pereira ${ }^{1}$, Alberto J.S. Macêdo ${ }^{3}$, \\ Rosângela C.S. Ramos ${ }^{4}$, and Messias S. Nogueira ${ }^{1}$
}

'Universidade Federal da Paraíba,km 12, Rodovia PB-079, 58397-000,Areia, Brasil. .Corresponding author (g_ferreira_dm@hotmail.com). ${ }^{2}$ Universidade Federal do Maranhão, km 04, Boa Vista s/n, 65500-000, Chapadinha, Brasil.

${ }^{3}$ Universidade Federal de Viçosa, Av. Peter Henry Rolfs, 36570-900, Viçosa, Brasil.

${ }^{4}$ Universidade Estadual do Sudoeste da Bahia, 7555, Av. Paralela, 45700-000, Itapetinga, Brasil.

Received: 13 April 2021; Accepted: 21 July 2021; doi:10.4067/S0718-58392021000400575

\begin{abstract}
It is essential to determine the productive potential and quality of forage sorghum (Sorghum bicolor (L.) Moench) silages using alternative and organic inputs, such as poultry litter (PL), intending to higher efficiency, and sustainable development of animal production systems in the world. Poultry litter fertilization has been widely used in crops for silage production, where it is believed that fertilization with PL can influence the fermentation profile and composition of forage sorghum silages. The objective of this study was to evaluate different levels of fertilization with PL on the agronomic and quality characteristics of forage sorghum silage 'BRS Ponta Negra'. For determination of agronomic and productive characteristics, randomized blocks design was adopted, the treatments were different PL levels: 5, 10, and $15 \mathrm{Mg} \mathrm{ha}^{-1}$. While for the evaluation of silage characteristics, the design was completely randomized. With fertilizer doses, a linear increase was observed for plant height, stem diameter, leaf length, and consequently for fresh and DM productions. Linear reduction was observed for neutral detergent fiber, while crude protein and $\mathrm{pH}$ contents of silages increased linearly with PL levels. Quadratic effect occurred for gas and effluent losses. Poultry litter may be an alternative source to supply the $\mathrm{N}$ needs in the production of sorghum for silage under experimental similar conditions. Associating productivity with cultivation efficiency, the PL level $13.46 \mathrm{Mg} \mathrm{ha}^{-1}$ is recommended for presenting the highest $\mathrm{N}$ agronomic efficiency and good nutritional quality of the silage.
\end{abstract}

Key words: Efficiency, forage conservation, nitrogen, organic fertilization, productivity.

\section{INTRODUCTION}

Sorghum (Sorghum bicolor (L.) Moench) is generally proposed as a resilient alternative to corn (Zea mays L.) under conditions of scarcer water availability (Roby et al., 2017) for silage production, due to its higher drought tolerance, water-use efficiency, photosynthetic and transpiration rates adaptable to more limiting climatic conditions (Hasan et al., 2017; Roby et al., 2017), where the corn cultivation is usually impracticable or impossible. According to Newman et al. (2013), sorghum needs an average of $30 \%$ less water than corn to present good forage production, in addition to requiring less $\mathrm{N}$ fertilization. 
Although sorghum is generally associated with crops under lower fertility and water stress conditions, it is very responsive to $\mathrm{N}$ fertilizers that seek to increase its productivity, presenting a high capacity to use the $\mathrm{N}$ provided by the fertilizer (Rani et al., 2019), whether this mineral or organic. As the farm decisions are guided by economic factors, the adoption of poultry litter (PL) as $\mathrm{N}$ fertilization may have greater economic benefits than commercial fertilizers, due to less capital investment and good productivity response (Hoover et al., 2019).

The effectiveness of PL depends on its composition and environmental conditions (Ibrahim et al., 2014). Its composition varies according to the age and diet of the animal as well as the moisture content, storage time of manure (Amanullah et al., 2010), number of birds per area, type of material used for litter, and other management factors, besides environmental factors during production, storage, and post-production handling methods (Ritz and Merka, 2009). Moreover, PL can be adopted as a supplementary alternative to phosphate fertilization as it results in availability similar to conventional management with commercial sources, in which the mineralization of organic P outcome in moderately available fractions of the soil throughout the cultivation (Poblete-Grant et al., 2020).

There are in the literature some studies that have already demonstrated that PL results in improved physical properties and soil fertility, mostly due to improvements of electrical conductivity, cation exchange capacity, $\mathrm{pH}$, porosity, and moisture, reduced bulk density; also, the improvement of nutrient availability such as $\mathrm{P}, \mathrm{K}, \mathrm{Ca}, \mathrm{Mg}$, and mainly $\mathrm{N}$ (AlGaadi et al., 2019; Hoover et al., 2019), as the organic matter decomposes.

Several studies have evaluated the effects of organic fertilization with PL on the cultivation of sorghum in many countries and regions around the world (Ibrahim et al., 2014; Penn et al., 2014; López-Sandin et al., 2019). Nevertheless, studies evaluating the effect of PL on forage sorghum for silage are scarce in the literature. In this case, it is believed that fertilization with PL improves the agronomic and productive parameters of the 'BRS Ponta Negra' sorghum, resulting in silages with an adequate fermentative profile.

In this sense, it is essential to determine the productive potential and quality of forage sorghum silages using alternative and organic inputs, such as PL, intending to higher efficiency, and sustainable development of animal production systems in the world. This study aimed, therefore, to investigate the influence of PL levels as the only $\mathrm{N}$ fertilization source, on the agronomic and silage quality traits of the forage sorghum variety.

\section{MATERIAL AND METHODS}

\section{Location and experimental area}

The experiment was conducted at the Fazenda Mata Limpa property, located in the municipality of Areia (6 $6^{\circ} 58^{\prime} 0^{\prime \prime} \mathrm{S}$, $35^{\circ} 44^{\prime} 0^{\prime \prime}$ W; 627 m a.s.1.), state of Paraíba, Brazil. The climate is classified according to Köppen as hot and humid (As') type, with rains from June to August, with average annual temperatures around $24^{\circ} \mathrm{C}$, relative humidity around $80 \%$, with an average rainfall of $1400 \mathrm{~mm} \mathrm{yr}^{-1}$, with water shortage for almost every year.

Monthly variables were measured at the Meteorological Station of the Federal University of Paraíba (UFPB), Agrarian Sciences Center, Areia, for rainfall, precipitation, and mean temperature during the experimental period of the first part of the experiment, focused on the cultivation of sorghum, which held between 6 June and 13 September 2013 (Table 1).

\section{Fertilization and planting}

Before carrying out planting, soil samples from the experiment area were collected, at a depth of 0-20 cm, to characterize fertility and perform chemical analysis. The analyses were conducted at the Soil Fertility Laboratory of the Agricultural Sciences Center at the UFPB in Areia.

Table 1. Monthly climatic variables during the experimental period.

\begin{tabular}{lrrrc}
\hline Climatic variables & June & July & August & September \\
\hline Rainfall, d & 25.0 & 21.0 & 10.0 & 22.0 \\
Precipitation, mm & 221.2 & 263.7 & 124.0 & 60.0 \\
Average temperature, ${ }^{\circ} \mathrm{C}$ & 22.2 & 21.4 & 21.5 & 22.5 \\
Relative humidity, $\%$ & 88.8 & 88.0 & 86.0 & 85.0 \\
\hline
\end{tabular}


After carrying out the soil analysis (Table 2), there was no need for liming; only fertilization with phosphate and $\mathrm{K}$ base with $50 \mathrm{~kg} \mathrm{ha}^{-1} \mathrm{P}_{2} \mathrm{O}_{5}$ and $50 \mathrm{~kg} \mathrm{ha}^{-1} \mathrm{~K}_{2} \mathrm{O}$, was made, using simple superphosphate and potassium chloride, respectively. The planting of sorghum (Sorghum bicolor (L.) Moench) 'BRS Ponta Negra' was done manually on 6 June 2013, in plots of $4.0 \mathrm{~m}^{2}(2.0 \times 2.0 \mathrm{~m})$, with a spacing of $0.7 \mathrm{~m}$ between lines.

Thinning was carried out $15 \mathrm{~d}$ after sowing, conserving 12 plants per linear meter. After planting, samples of the organic fertilizer PL were collected from the rural property where the research was implemented, for chemical analysis (Table 3) also conducted by the soil fertility laboratory at UFPB.

\section{Agronomic and productive parameters}

For determination of the agronomic and productive characteristics, it was adopted the experimental design in randomized blocks, with four treatments and four replicates, treatments were different levels of poultry litter (PL): 5, 10, and $15 \mathrm{Mg}$ $\mathrm{ha}^{-1}$. While for the evaluation of silage characteristics, the design used was completely randomized, using the same levels of PL and four replicates per treatment.

The cycle occurred from planting to harvest at $103^{\text {rd }}$ day of the experiment. Initially, agronomic evaluations of plant morphometry and density were carried out before harvest, for the measurement it was considered the production of $2 \mathrm{~m}$ of line per plot, measured with a measuring tape: plant height (PH), stem diameter (SD), and average leaf length (ALL), all in $\mathrm{cm}$. The number of leaves per plant $\left(\mathrm{NL}_{\text {plant }}{ }^{-1}\right)$ was counted and considering the number of tillers per linear meter cultivated the number of plants per linear meter was determined; then, it was multiplied by the total of linear meters in 1 ha to estimate the average number of plants per hectare (plants ha ${ }^{-1}$ ).

Harvesting was carried out when most grains had a milky/pasty stage. The cut was made manually, where the collection of $2 \mathrm{~m}$ of line per plot was separated into a panicle, leaf blade, dead material, and stalk, which were weighed and dried in oven at $65{ }^{\circ} \mathrm{C}$ until reaching constant weight. Then they were weighed again to estimate DM content. This methodology is intended to determine plant components in the DM (\%), which are leaf blade, stem, panicle, and dead material.

Fresh matter production (FMP) per hectare was obtained by the product between the production per cultivated linear meter and the total of linear cultivated meters per hectare. Dry matter production (DMP) was estimated by the product between the fresh mass production and the DM content, which is posteriorly converted to DMP ha-1.

For a complete assessment of the effects of the fertilizer supplies, application rates must be compared with a treatment with $0 \mathrm{~N}$, which allows quantifying the contribution of the $\mathrm{N}$ supply of the soil without fertilization, represented by the treatment of $0 \mathrm{Mg} \mathrm{ha}^{-1}$. Therefore, with the determination of DMP and exact values of $\mathrm{N}$ supply $(86.59,173.18$, and 259.78 $\mathrm{kg} \mathrm{N} \mathrm{ha}^{-1}$ for 5, 10, and $15 \mathrm{Mg} \mathrm{ha}^{-1} \mathrm{PL}$, respectively) (Table 3) it was possible to determine the agronomic efficiency of the applied $\mathrm{N}\left(\mathrm{AE}_{\mathrm{N}}\right)$ via PL, according to the formula proposed by Dobermann (2005):

$$
\mathrm{AE}_{\mathrm{N}}=\mathrm{Y}_{\mathrm{N}} / \mathrm{F}_{\mathrm{N}}
$$

where $\mathrm{AE}_{\mathrm{N}}$ is agronomic efficiency of applied $\mathrm{N}\left(\mathrm{kg}\right.$ DMP increase $\mathrm{kg}^{-1} \mathrm{~N}$ applied), $\mathrm{Y}_{\mathrm{N}}$ is crop yield with applied $\mathrm{N}$ $\left(\mathrm{kg} \mathrm{DM} \mathrm{ha}{ }^{-1}\right), \mathrm{F}_{\mathrm{N}}$ is applied $\mathrm{N}$ rate with a fertilizer treatment $\left(\mathrm{kg} \mathrm{N} \mathrm{ha}^{-1}\right)$.

Table 2. Soil chemical composition of the experimental area.

\begin{tabular}{|c|c|c|c|c|c|c|c|c|c|c|c|}
\hline $\mathrm{pH}_{\left(\mathrm{H}_{2} \mathrm{O}\right)}$ & $\mathrm{P}$ & $\mathrm{K}^{+}$ & $\mathrm{Na}$ & $\mathrm{H}^{+}+\mathrm{Al}^{+3}$ & $\mathrm{Al}^{+3}$ & $\mathrm{Ca}^{+2}$ & $\mathrm{Mg}^{+2}$ & SB & CTC & $\mathrm{V}$ & $\mathrm{OM}$ \\
\hline & $-n$ & ${ }^{-3}-$ & $\longrightarrow$ & & 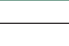 & $\mathrm{cmol}_{\mathrm{c}} \mathrm{dm}^{-3}$ & & & - & $\%$ & $\mathrm{~g} \mathrm{~kg}^{-1}$ \\
\hline 6.18 & 5.75 & 22.21 & 0.00 & 2.19 & 0.00 & 1.60 & 0.56 & 2.216 & 4.40 & 50.36 & 19.43 \\
\hline
\end{tabular}

$\mathrm{H}^{+}+\mathrm{Al}^{+3}$ : Potential acidity; SB: sum of bases; CTC: cation exchange capacity; V: saturation/base; OM: organic matter.

Table 3. Chemical characterization of the poultry litter used in the experiment.

\begin{tabular}{|c|c|c|c|c|c|c|c|c|c|c|c|}
\hline $\mathrm{N}$ & $\mathrm{Ca}$ & $\mathrm{P}$ & $\mathrm{Mg}$ & $\mathrm{K}$ & $\mathrm{OM}$ & $\mathrm{Fe}$ & $\mathrm{Mn}$ & $\mathrm{Zn}$ & $\mathrm{Cu}$ & $\mathrm{pH}$ & Moisture \\
\hline & 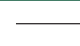 & $\mathrm{g}$ & 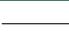 & $\bar{L}$ & & & $\mathrm{mg} \mathrm{kg}^{-1}$ & & - & & $\%$ \\
\hline 25.32 & 34.33 & 19.17 & 8.85 & 25.26 & 706.80 & 442.50 & 704.70 & 436.44 & 121.28 & 8.15 & 31.60 \\
\hline
\end{tabular}

OM: Organic matter. 


\section{Ensiling process and analysis}

The rest of the material from all the plots of each treatment was chopped in a stationary forage machine regulated to cut the forage into particles of approximately $2 \mathrm{~cm}$, and posteriorly was homogenized to be ensiled in PVC silos, which represent the experimental units of the silage test. Samples composed of sorghum were collected before the ensiling process to determine its physical-chemical composition (Table 4).

During the study, 16 experimental PVC silos were made, with $15 \mathrm{~cm}$ in diameter and $40 \mathrm{~cm}$ in height, where the material was compacted to achieve a specific mass of $500 \mathrm{~kg} \mathrm{~m}^{-3}$ of fresh matter. The fermentation period occurred for $30 \mathrm{~d}$. The entire ensiling process took place at the Forage Laboratory UFPB.

Laboratory analyses were performed at the Animal Nutrition and Food Analysis Laboratory of UFPB. The compositions in $\mathrm{DM}$, mineral matter $(\mathrm{MM})$, and crude protein $(\mathrm{CP})$ were made according to the methodologies recommended by AOAC (1990), with adaptations by Detmann et al. (2012). For the determination of neutral detergent fiber (NDF), the methodology recommended by Mertens (2002) was used.

Concentration of water-soluble carbohydrates (WSC) was evaluated by the concentrated sulfuric acid method, described by Dubois et al. (1951) with adaptations by Corsato et al. (2008). The determination of $\mathrm{pH}$ in distilled water occurred in duplicate, collecting approximately $25 \mathrm{~g}$ sample of the ensiled material from each treatment and adding $100 \mathrm{~mL}$ water. After $1 \mathrm{~h}$, results were read with a potentiometer according to the methodology described by Bolsen et al. (1992). For estimating gas losses (GL) and effluent losses (EL), equations described by Zanine et al. (2010) were used.

\section{Statistical analysis}

The data were submitted to ANOVA and regression to determine the effect of the levels of PL, using the statistical analysis program Sisvar (Ferreira, 2010). Among the criteria for choosing regression models, the significance of the parameters estimated by the models, and the values of the determination coefficients were adopted.

\section{RESULTS}

The results revealed that with the adoption of increasing levels of fertilization with PL, there was a positive quadratic effect $(\mathrm{p}<0.05)$ for the percentage of leaf of sorghum, it was observed with the derivation of the regression equation the maximum point for this variable at the fertilization level $8.23 \mathrm{Mg} \mathrm{ha}^{-1}$ (Table 5). However, there was a negative quadratic effect observed for the stem component, where the fertilization level of $8.53 \mathrm{Mg} \mathrm{ha}^{-1}$ represented the minimum point for percentage of the variable.

Regarding the proportions of percentage of panicle and dead material, the positive quadratic effect $(\mathrm{p}<0.05)$ also occurred, in which $9.72 \mathrm{Mg} \mathrm{ha}^{-1}$ resulted in the maximum participation point for the panicle. The lowest content of dead material $(\mathrm{p}<0.05)$ was observed for the treatment without fertilization $\left(0 \mathrm{Mg} \mathrm{ha}^{-1}\right)($ Table 5$)$.

Regarding the measurements that define plant growth, it was found that with increasing fertilization doses via PL, there was an increasing effect $(\mathrm{p}<0.05)$ for PH, SD, and ALL (Table 6). This indicates that these variables responded positively to the fertilization dosages adopted in the research, where the maximum point noticed for these variables was at the highest level of fertilization with PL. The highest PL fertilization rate (15 Mg ha-1) resulted in an increase of 24.39\% compared to the control. For number of leaves per plant $\left(\mathrm{NL} \mathrm{plant}^{-1}\right)$, fertilization levels did not influence $(\mathrm{p}>0.05)$ this variable, obtaining a mean of 9.256 leaves per plant. Concerning the plants $\mathrm{ha}^{-1}$, no effects of PL levels ( $\left.\mathrm{p}>0.05\right)$ were observed, with no model adjustment occurring and these presented an average of 122.812 plants ha $^{-1}$.

Table 4. Physico-chemical composition of the forage sorghum plant 'BRS Ponta Negra' at $103 \mathrm{~d}$ after planting.

\begin{tabular}{cccccc}
\hline Fertilization levels & DM & NDF & WSC & OM & MM \\
\hline $\mathrm{Mg} \mathrm{ha}^{-1}$ & 21.39 & 77.84 & 21.81 & 96.96 & 3.31 \\
0 & 21.80 & 77.05 & 20.59 & 96.03 & 3.97 \\
5 & 22.79 & 76.89 & 24.12 & 95.82 & 4.18 \\
10 & 22.92 & 73.23 & 23.66 & 95.71 & 4.29 \\
15 & &
\end{tabular}

DM: Dry matter; NDF: neutral detergent fiber; WSC: water-soluble carbohydrates; OM: organic matter; MM: mineral matter. 
Table 5. Average values for proportion of components of the 'BRS Ponta Negra' forage sorghum plants (DM based) submitted to increasing levels of organic fertilization with poultry litter.

\begin{tabular}{lcccc}
\hline Levels & Leaf blade $^{1}$ & Stem $^{2}$ & Panicle $^{3}$ & Dead material $^{4}$ \\
\hline $\mathrm{Mg} \mathrm{ha}^{-1}$ & $\%$ & $\%$ & $\%$ & $\%$ \\
0 & 11.60 & 77.72 & 8.93 & 1.73 \\
5 & 17.22 & 69.57 & 10.54 & 2.65 \\
10 & 16.77 & 68.54 & 11.52 & 3.16 \\
15 & 13.83 & 73.55 & 10.53 & 2.08 \\
CV, $\%$ & 6.32 & 25.53 & 73.69 \\
Regression equations: & 13.44 & & & $\mathrm{R}^{2}$ \\
${ }^{1} \hat{\mathrm{Y}}=11.779+1.4088 \mathrm{x}-0.0856 \mathrm{x}^{2}$ & & & 96.93 \\
${ }^{2} \hat{\mathrm{Y}}=77.666-2.2448 \mathrm{x}+0.1316 \mathrm{x}^{2}$ & & & 99.89 \\
${ }^{3} \hat{\mathrm{Y}}=8.863+0.5056 \mathrm{x}-0.026 \mathrm{x}^{2}$ & & & 97.40 \\
${ }^{4} \hat{\mathrm{Y}}=1.671+0.3312 \mathrm{x}-0.02 \mathrm{x}^{2}$ & & & 94.16 \\
\hline
\end{tabular}

CV: Coefficient of variation.

When evaluating the sorghum crop productivity, it is evident that there was an increasing linear effect $(\mathrm{p}<0.05)$ for FMP, ranging from $37803.2 \mathrm{~kg} \mathrm{ha}^{-1}$ at $0 \mathrm{Mg} \mathrm{ha}^{-1} \mathrm{PL}$ fertilization to $55831.7 \mathrm{~kg} \mathrm{ha}^{-1}$ for $15 \mathrm{Mg} \mathrm{ha}^{-1}$ (Table 7), increasing by $32.29 \%$. A similar effect was observed for DMP with a variation from 8086.1 to $12796.6 \mathrm{~kg} \mathrm{ha}^{-1}$, represented by an increase of $36.81 \%$, which is $4.15 \%$ higher than for FMP. However, for $\mathrm{N}$ agronomic efficiency (NAE), which represents the increase in DMP, a quadratic effect $(\mathrm{p}<0.05)$ was evident with the increasing fertilization doses, where the maximum NAE was at $13.46 \mathrm{Mg} \mathrm{ha}^{-1}$, which indicates that after this level NAE tends to decrease.

Table 6. Average values for morphometric evaluations of 'BRS Ponta Negra' sorghum plants submitted to increasing levels of organic fertilization per poultry litter.

\begin{tabular}{|c|c|c|c|c|c|}
\hline Levels & $\mathrm{PH}^{1}$ & $\mathrm{NL}_{\text {plant }}{ }^{-12}$ & $\mathrm{SD}^{3}$ & $\mathrm{ALL}^{4}$ & Plants ha ${ }^{-1}$ \\
\hline $\mathrm{Mg} \mathrm{ha}^{-1}$ & $\mathrm{~cm}$ & & $\mathrm{~cm}$ & $\mathrm{~cm}$ & \\
\hline 0 & 224.7 & 9.23 & 1.34 & 11.31 & 129.375 \\
\hline 5 & 233.2 & 9.25 & 1.46 & 12.68 & 123.750 \\
\hline 10 & 274.0 & 9.25 & 1.55 & 12.75 & 124.375 \\
\hline 15 & 297.2 & 9.33 & 1.60 & 12.86 & 113.750 \\
\hline $\mathrm{CV}, \%$ & 14.61 & 7.07 & 9.47 & 16.47 & 7.31 \\
\hline \multicolumn{5}{|c|}{ Regression equations: } & $\mathrm{R}^{2}$ \\
\hline \multicolumn{5}{|c|}{${ }^{1} \hat{Y}=218.53+5.166 x$} & 94.92 \\
\hline \multicolumn{5}{|c|}{${ }^{2} \hat{Y}=9.265$} & - \\
\hline \multicolumn{5}{|c|}{${ }^{3} \hat{Y}=1.357+0.0174 x$} & 96.85 \\
\hline \multicolumn{5}{|c|}{${ }^{4} \hat{Y}=11.692+0.0944 x$} & 69.59 \\
\hline
\end{tabular}

PH: Plant height; NL plant ${ }^{-1}$ : number of leaves per plant; SD: stem diameter; ALL: average leaf length; CV: coefficient of variation.

Table 7. Average values for fresh matter production (FMP), dry matter production (DMP), and N agronomic efficiency (NAE) of 'BRS Ponta Negra' forage sorghum plants submitted to increasing levels of organic fertilizer with poultry litter.

\begin{tabular}{lrrc}
\hline Levels & $\mathrm{FMP}^{1}$ & $\mathrm{DPM}^{2}$ & $\mathrm{NAE}^{3}$ \\
\hline $\mathrm{Mg} \mathrm{ha}^{-1}$ & $\mathrm{Mg} \mathrm{ha}^{-1}$ & $\mathrm{Mg} \mathrm{ha}^{-1}$ & $\mathrm{~kg} \mathrm{MS} \mathrm{kg}^{-1} \mathrm{~N}$ \\
0 & 37803.2 & 8086.1 & 0.00 \\
5 & 40860.2 & 8907.5 & 9.49 \\
10 & 50248.6 & 11451.6 & 19.43 \\
15 & 55831.7 & 12796.6 & 18.13 \\
$\mathrm{CV}, \%$ & 13.51 & & \\
Regression equations: & & & $\mathrm{R}^{2}$ \\
${ }^{1} \hat{\mathrm{Y}}=36665+1269.5 \mathrm{x}$ & & & 96.77 \\
${ }^{2} \hat{\mathrm{Y}}=7809.1+333.51 \mathrm{x}$ & & & 96.56 \\
${ }^{3} \hat{\mathrm{Y}}=-0.5845+2.9051 \mathrm{x}-0.1079 \mathrm{x}^{2}$ & & 97.03 \\
\hline
\end{tabular}

$\mathrm{CV}$ : Coefficient of variation. 
Regarding the bromatological composition of sorghum silages, a linear reduction $(\mathrm{p}<0.05)$ of NDF content was observed. For CP, an enhance at the linear effect was noticed ( $\mathrm{p}<0.05)$, with the maximum of $7.45 \%$ for fertilization 15 $\mathrm{Mg} \mathrm{ha}^{-1}$, which represents an increase of $8.59 \%$ compared to the control. There was a negative quadratic effect $(\mathrm{p}<0.05)$ for WSC concentrations, in which the critical point estimated by linear regression is situated at $7.65 \mathrm{Mg} \mathrm{ha}^{-1}$, indicating that this level of PL fertilization had the lowest value for WSC. However, for DM, OM, and MM, no effects ( $p>0.05)$ of PL were perceived, although a considerable variation can be observed for the values mainly of MM (Table 8).

In the fermentative characteristics of the silages, $\mathrm{N}_{-} \mathrm{NH}_{3}$ and $\mathrm{pH}$ were increasing $(\mathrm{p}<0.05)$ with PL fertilization for the 'BRS Ponta Negra' sorghum. For pH, values ranged from 3.64 to 3.76 for extreme levels of fertilization ( 0 and $15 \mathrm{Mg} \mathrm{ha}^{-1}$, respectively), which represents an increase of $3.19 \%$. There was an effect of fertilizer doses on gases and effluent losses, with a negative quadratic effect $(\mathrm{p}<0.05)$ for GL; moreover, through the derivation of the equation, it was noticed that the lowest losses occurred at the critical point of $3.54 \mathrm{Mg} \mathrm{ha}^{-1}$. Similarly, the quadratic behavior $(\mathrm{p}<0.05)$ was observed for EL, although, with the lowest effluent losses at $7.75 \mathrm{Mg} \mathrm{ha}^{-1}$.

\section{DISCUSSION}

The lower stem percentage proportion at 5 and $10 \mathrm{Mg} \mathrm{ha}^{-1}$ combined with a percentage rise for the other evaluated components, confirms that this variable presented a negative correlation for the percentage of the leaf blade, panicle, and dead material in the plant DM.

The stem, although relevant in the silage fermentation process due to high content of WSC (main substrate for lactic fermentation responsible for the preservation of the material) (Moura et al., 2017), it is not recommended because it has concentrations much higher than the percentage of leaf blade and panicle. This is because leaf blade and panicle play important roles in the nutritional quality of silage since they have the highest digestibility coefficients. Besides, the panicle is essential in regulating the DM content at harvest and ensiling process (Santos et al., 2013). There was a slight increase in these DM levels of the plant (Table 4), as the dosages promote a higher percentage of panicles compared to control.

These mean percentages of the components are justified by 'BRS Ponta Negra' being geared to forage production and, therefore, not having high participation of panicles. As for dead material, it is believed that it increased together with the development of panicles due to a high mobilization of components assimilated in the leaf for the development of grains, since this is a considerable drain at the beginning of the reproductive period, which results in the appearance of senescent leaves (Simioni et al., 2014).

The SD has a total correlation with the percentage of bedridden or broken plants (Santos et al., 2013), in which, with increasing levels of PL fertilization, it is evident that the increase in diameter further reinforces the prevention of occurrence. Number of plants per hectare is not necessarily correlated with the increase in crop productivity, unlike PH.

Although PL fertilization levels increased the other variables that represent the plant's growth attributes $(\mathrm{PH}, \mathrm{SD}$, and ALL), directly influenced the increase in FMP (Table 7). As the DM content of the plant before ensiling (Table 4) was close, the increasing dosages of PL also resulted in a linear increase in DMP. It is evident then that forage yield is related to the growth parameters mentioned above.

Table 8. Average values for the physical-chemical composition of silages of 'BRS Ponta Negra' forage sorghum plants submitted to increasing levels of fertilization with poultry litter.

\begin{tabular}{lcccccc}
\hline Levels & $\mathrm{DM}$ & $\mathrm{NDF}^{1}$ & $\mathrm{CP}^{2}$ & $\mathrm{WSC}^{3}$ & $\mathrm{OM}$ & $\mathrm{MM}$ \\
\hline $\mathrm{Mg} \mathrm{ha}^{-1}$ & $\%$ & $\%$ & $\%$ & $\%$ & $\%$ & $\%$ \\
0 & 22.02 & 76.87 & 6.81 & 13.79 & 96.02 & 3.97 \\
5 & 23.47 & 75.55 & 6.83 & 12.05 & 96.07 & 3.93 \\
10 & 21.94 & 75.33 & 7.41 & 10.29 & 93.17 & 6.82 \\
15 & 23.24 & 73.41 & 7.45 & 14.09 & 95.45 & 4.51 \\
$\mathrm{CV}, \%$ & 0.73 & 2.33 & 5.82 & 17.80 & 1.82 & 37.75 \\
Regression equations: & & & & & & $\mathrm{R}^{2}$ \\
${ }^{1} \hat{\mathrm{Y}}=76.88-0.212 \mathrm{x}$ & & & & & & 92.10 \\
${ }^{2} \hat{\mathrm{Y}}=6.75+0.05 \mathrm{x}$ & & & & & 83.76 \\
${ }^{3} \hat{\mathrm{Y}}=14.069-0.8482 \mathrm{x}+0.0554 \mathrm{x}^{2}$ & & & & & 83.20 \\
\hline
\end{tabular}

DM: Dry matter; NDF: neutral detergent fiber; CP: crude protein; WSC: water-soluble carbohydrates; OM: organic matter; MM: mineral matter; CV: coefficient of variation. 
The increasing levels of PL fertilization improved physical characteristics and soil fertility through enhancing availability of nutrients in concentrations that meet the sorghum absorption demand. These result in a further root growth with an increase in water and nutrients collection, mainly $\mathrm{N}$; thus, favoring cell division, elongation of culture, and meristematic activity (Mahfouz et al., 2015; Wen et al., 2016) during the $103 \mathrm{~d}$ of cultivation. The photosynthetic surface is, therefore, added with higher sunlight collecting and efficiency of metabolic processes. It results in a higher accumulation of photoassimilates, which, in turn, led to an increase in plant height, SD, NL plant ${ }^{-1}$, and consequently, FMP and DMP. It is worth mentioning that this characteristic is highly positive as it shows that organic fertilization results in greater availability of nutrients for the diet of the ruminants of the productive nucleus in which the cultivation is inserted.

All these results indicate that forage sorghum is a crop very responsive to $\mathrm{N}$ fertilization since it is not a legume, and the $\mathrm{N}$ supply to the crop entirely come from what is offered in the soil. Besides, in conditions of good distribution and rainfall occurrence, mineralization tends to be more accelerated, confirming, thus, the efficacy of fertilizers in this study. Therefore, PL is a good alternative for total or partial replacement of commercial inorganic fertilizers, as already mentioned in some research studies, which report that the agronomic efficiency of organic fertilizers derived from poultry residues is equal to or greater than that of soluble mineral products (Penn et al., 2014; Hentz et al., 2016).

López-Sandin et al. (2019), in a research with low rainfall (250 to $\left.500 \mathrm{~mm} \mathrm{yr}^{-1}\right)$, indirectly demonstrated these statements when comparing PL fertilization of $60 \mathrm{~kg} \mathrm{~N}^{-1}$ with chemical fertilizer $100 \mathrm{~kg} \mathrm{~N}(50 \mathrm{~kg} \mathrm{~N}$ at sowing and $50 \mathrm{~kg}$ after $25 \mathrm{~d})$. Through the effect of the equation proposed by Dobermann (2005) for NAE, PL fertilization resulted in an increase of $42 \mathrm{~kg}$ DM for each $1 \mathrm{~kg} \mathrm{~N}$ fertilization, while inorganic fertilization resulted in an increase of $16.6 \mathrm{~kg}$ DM for each $1 \mathrm{~kg} \mathrm{~N}$ supplied to the crop. However, in conditions of better water availability, NAE tends to be similar, as in the research conducted by Abdalla et al. (2007).

It would seem that inorganic fertilization was less efficient in low water restriction, probably because it had superior losses due to leaching. On the other hand, in good water availability, NAE of PL and inorganic N fertilizers seem to show similarity. In the present study, it is understood that mineralization affects $\mathrm{N}$ supply in dosages above $13.08 \mathrm{Mg} \mathrm{ha}^{-1}$, although higher dosages may continue to favor an increase in FMP and DMP, as shown in Table 7.

It is known that chemical composition at the gathering time of the material (Table 4) directly influences the fermentation quality occurring in the silo, and this is changed depending on the amount of $\mathrm{N}$ used for fertilization (McDonald et al., 1991).

Although no linear models were observed for the concentration of MM and OM (Table 8), they represent the DM partition and are inversely proportional. During the lactic fermentation in the silo, there was a considerable reduction of organic nutrients, especially WSC, resulting in decreased OM partition in DM and an increase in the MM proportion, which is observed, above all, at the fertilization level of $10 \mathrm{Mg} \mathrm{ha}^{-1}$. Therefore, fermentation generally presents inductions and changes in these proportions of OM and MM. Additionally, increasing PL levels also result in greater availability of minerals such as $\mathrm{P}, \mathrm{K}, \mathrm{Mg}$, and $\mathrm{Ca}$ into the soil, leading to greater absorption of these minerals (Agbede and Ojeniyi, 2010) and a slightly increasing in the percentage of MM in the composition of pre-ensiled forage (Table 4).

The residual levels of WSC found for silages may lead to the conclusion that the fermentation process at $10 \mathrm{Mg} \mathrm{ha}^{-1}$ was more intense than the others, considering that $57.34 \%$ WSC was consumed by microorganisms in the fermentation process. While $36.77 \%, 41.47 \%$, and $40.45 \%$ were used as a substrate at 0,5 , and $15 \mathrm{Mg} \mathrm{ha}^{-1}$, respectively. Nevertheless, these did not result in considerable $\mathrm{pH}$ reductions (Table 9) that would affect silage quality.

Almodares et al. (2009) observed that increasing $\mathrm{N}$ doses (50, 100, 150, and $200 \mathrm{~kg}$ urea ha $\left.{ }^{-1}\right)$ resulted in a linear decrease in WSC concentration of sorghum. It was probably due to the $\mathrm{N}$ fixation metabolism since part of the intermediate metabolism of the Krebs cycle is used for the synthesis of amino acids and proteins, the amount of carbohydrates is reduced, especially in crops rich in sugar, such as sorghum. The results obtained showed that this fact did not occur in the present study, since the sorghum harvest was early, with DM levels below that recommended by the literature, which is 30\%-35\% DM (McDonald et al., 1991).

As 'BRS Ponta Negra' has a succulent stem and there was a high rainfall during the experimental period, this low DM level is explained. If the harvest occurred later, it would probably result in greater participation of panicles and an increase in DM levels (Saini, 2012). However, it is not recommended to harvest sorghum in stages of farinaceous grains because the absence of tannin in this cultivar would lead to attack by birds and loss of grains, besides increasing the percentage of dead material in plants and possibly increasing NDF levels. 
Table 9. Average values for ammoniacal $\mathrm{N}\left(\mathrm{N}-\mathrm{NH}_{3}\right)$, $\mathrm{pH}$, gas losses (GL), and effluent losses (EL) in silages of 'BRS Ponta Negra' forage sorghum plants submitted to increasing levels of fertilization with poultry litter.

\begin{tabular}{lcccc}
\hline Levels & ${ }^{1} \mathrm{~N}^{-\mathrm{NH}_{3}}$ & ${ }^{2} \mathrm{pH}$ & ${ }^{3} \mathrm{GL}$ & ${ }^{4} \mathrm{EL}$ \\
\hline $\mathrm{Mg} \mathrm{ha}^{-1}$ & \% N Total & & $\% \mathrm{DM}$ & $\mathrm{kg} \mathrm{t}^{-1} \mathrm{GM}$ \\
0 & 4.28 & 3.64 & 7.98 & 18.63 \\
5 & 4.44 & 3.67 & 7.82 & 12.73 \\
10 & 4.95 & 3.74 & 8.12 & 9.66 \\
15 & 5.81 & 3.76 & 8.21 & 18.42 \\
$\mathrm{CV}, \%$ & & 12.01 & 41.85 \\
Regression equations: & & & $\mathrm{R}^{2}$ \\
${ }^{1} \hat{\mathrm{Y}}=4.105+0.102 \mathrm{x}$ & & & 91.39 \\
${ }^{2} \hat{\mathrm{Y}}=3.638+0.0086 \mathrm{x}$ & & & 95.56 \\
${ }^{3} \hat{\mathrm{Y}}=7.9465+0.0177 \mathrm{x}+0.0025 \mathrm{x}^{2}$ & & & 74.22 \\
${ }^{4} \hat{\mathrm{Y}}=19.0838-2.2720 \mathrm{x}+0.1465 \mathrm{x}^{2}$ & & & 93.07 \\
\hline
\end{tabular}

GL: Gas losses; EL: effluent losses; GM: green matter; CV: coefficient of variation.

In the present study, as $10 \mathrm{Mg} \mathrm{ha}^{-1}$ exhibited the lowest WSC percentages, these also presented the lowest value for DM content. The absence of changes in the levels of fertilization on the silage DM (Table 8) is interconnected with the percentage variations that occur in other plant nutrients since the fermentation of forage crops is very complex and involves many types of microorganisms, resulting in a variety of different end products (Kung et al., 2018).

Almodares et al. (2009) observed that there is a reduction in crude fiber content when there is a greater availability of $\mathrm{N}$ for sorghum crop. The same seems to have occurred in the present study for sorghum. It is believed that the decreasing contents of NDF, according to the fertilization levels, are more linked to the decrease of the fiber percentage in DM of the plant before ensiling (Table 4) than properly due to fermentation in the silo. The reduction in NDF contents is also correlated with the lower stem share at 5 and $10 \mathrm{Mg} \mathrm{ha}^{-1}$ since the stem contains more fibrous material than the panicle, added with the reduction of this component.

Organic fertilization results in increased $\mathrm{N}$ and $\mathrm{P}$ availability. It is important to stand out that $\mathrm{P}$ is the main component of ATP, which carries energy for metabolic processes. It would seem that with increasing PL dosages, there was an increase in biosynthesis and concentration of amino acids, resulting in higher protein synthesis (Saini, 2012), and thus, higher CP levels, as already verified by some researches (Almodares et al., 2009).

McDonald et al. (1991) stated that good quality silage generally presents $\mathrm{pH}$ values between 3.8 and 4.2. Therefore, although the proportions of panicles have remained low in all fertilization levels, $\mathrm{pH}$ values remained in the ranges of 3.64 and 3.76 (Table 9), showing that the $\mathrm{pH}$ did not reduce to critical levels that seriously affect silage quality.

The drop in pH may have occurred more slowly in silages fertilized with PL, as they have higher DM levels (Table 4) and therefore providing to the populations of proteolytic microorganisms a longer period of activity. Consequently, it resulted in a steady increase in the release of $\mathrm{N}^{-N_{3}}$ with increasing levels, providing that $\mathrm{CP}$ content of the plant was even higher than sorghum crop without PL fertilization.

The higher production of $\mathrm{N}^{-\mathrm{NH}_{3}}$ influenced the behaviors observed for $\mathrm{pH}$ and $\mathrm{PG}$ that were also increasing, as the

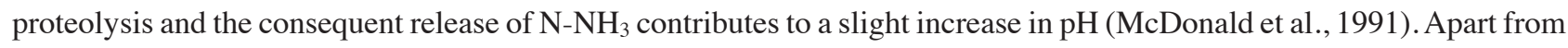
that, during the fermentation, the action of microorganisms that resulted in proteolysis (enterobacteria and Clostridium spp.), also act in the release of gases, mainly $\mathrm{CO}_{2}$ (McDonald et al., 1991).

Given that silages with $\mathrm{N}-\mathrm{NH}_{3}$ below $10 \%$ were considered to be of good quality (McDonald et al., 1991) and that in tropical regions the acceptable standard for PG is up to 9.5\% DM (Zanine et al., 2010), it was assumed that fermentation was not compromised by PL levels to the extent of affecting the consumption of silage by the animals. On the other hand, the CP levels are increased, and NDF is reduced, which is nutritionally favorable.

In brief, PL is a technically and economically viable management to increase the silage sorghum productivity, in which, in terms of utilization of organic manure compared to the chemical, it might reduce capital investment for fertilizers by 30\%-70\%. Besides, it has an excellent reduction of environmental impact (Lu and Shen, 2011), mainly the PL that presents concentration and availability of nutrients higher than other more common types of animal manure on the market (Dikinya and Mufwanzala, 2010). 


\section{CONCLUSIONS}

Fertilizing with poultry litter (PL) in sorghum 'BRS Ponta Negra' promotes higher crop productivity and the quality of the silage was not compromised. Associating productivity with cultivation efficiency, the PL level $13.46 \mathrm{Mg} \mathrm{ha}^{-1}$ is recommended for presenting the highest $\mathrm{N}$ agronomic efficiency and good nutritional quality of the silage.

Nevertheless, further research with PL levels in sorghum is required to investigate the effects on performance and feed intake of ruminants, which would prove the potential in farm conditions.

\section{REFERENCES}

Abdalla, M.A., Salih, N.O., Hassabo, A.A., and Mahala, A.G. 2007. Effect of application of organic amendments on quality of forage sorghum (Sorghum bicolor L.) in the semi-arid tropics. Archives of Agronomy and Soil Science 53:529-538.

Agbede, T.M., and Ojeniyi, S.O. 2010. Tillage and poultry manure effects on soil physical properties, nutrient status, growth, dry matter and grain yield of sorghum. Journal of Agricultural Science and Technology 4:45-59.

Al-Gaadi, K.A., Madugundu, R., and Tola, E. 2019. Investigating the response of soil and vegetable crops to poultry and cow manure using ground and satellite data. Saudi Journal of Biological Sciences 26(7):1392-1399.

Almodares, A., Jafarinia, M., and Hadi, M.R. 2009. The effects of nitrogen fertilizer on chemical compositions in corn and sweet sorghum. American-Eurasian Journal of Agricultural and Environmental Sciences 6:441-446.

Amanullah, M.M., Sekar, S., and Muthukrishnan, P. 2010. Prospects and potential of poultry manure. Asian Journal of Plant Sciences 9:172-182.

AOAC. 1990. Official methods of analysis of the association of official analytical chemists. Association of Official Analytical Chemists (AOAC), Arlington, Virginia, USA.

Bolsen, K.K., Lin, C., Brent, B.E., Feyerherm, A.M., Urban, J.E., and Aimutis, W.R. 1992. Effect of silage additives on the microbial succession and fermentation process of alfalfa and corn silages. Journal of Dairy Science 75:3066-3083.

Corsato, C.E., Scarpare Filho, J.A., e Sales, E.C.J. 2008. Teores de carboidratos em órgãos lenhosos do caquizeiro em clima tropical. Revista Brasileira de Fruticultura 30:414-418 [In Portuguese with English abstract].

Detmann, E., Souza, M.A., Valadares Filho, S.C., Queiroz, A.C., Berchielli, T.T., Saliba, E.O.S., et al. 2012. Métodos para análise de alimentos. Suprema, Visconde do Rio Branco, Brazil. Instituto Nacional de Ciência e Tecnologia de Ciência Animal (INCT-CA), Universidade Federal de Viçosa, Viçosa, Minas Gerais, Brasil.

Dikinya, O., and Mufwanzala, N. 2010. Chicken manure-enhanced soil fertility and productivity: Effects of application rates. Journal of Soil Science and Environmental Management 1:46-54.

Dobermann, A.R. 2005. Nitrogen use efficiency - State of the art. Agronomy \& Horticulture, Faculty Publications 316. University of Nebraska, Lincoln, Nebraska, USA.

Dubois, M., Gilles, K., Hamilton, J.K., Rebers, P.A., and Smith, F.S. 1951. A colorimetric method for the determination of sugars. Nature 168:167.

Ferreira, D.F. 2010. SISVAR - Sistema de análise de variância. Universidade Federal de Lavras (UFLA), Lavras, Brasil.

Hasan, S.A., Rabei, S.H., Nada, R.M., and Abogadallah, G.M. 2017. Water use efficiency in the drought-stressed sorghum and maize in relation to expression of aquaporin genes. Biologia Plantarum 61:127-137.

Hentz, P., Corrêa, J.C., Fontaneli, R.S., Rebelatto, A., Nicoloso, R.S., and Semmelmann, E.N. 2016. Poultry litter and pig slurry applications in an integrated crop-livestock system. Revista Brasileira de Ciência do Solo 40:1-12.

Hoover, N.L., Law, J.Y., Long, L.A.M., Kanwar, R.S., and Soupir, M.L. 2019. Long-term impact of poultry manure on crop yield, soil and water quality, and crop revenue. Journal of Environmental Management 252:109582.

Ibrahim, K.A., Mohammed, A.A., Mohamed, E.A., El Naim, A., Zaied, M.M.B., and El Khidir, E.R.E. 2014. Effect of chisel plough and chicken manure on growth and yield of sorghum (Sorghum bicolor (L.) Moench). Research Journal of Pharmaceutical, Biological and Chemical Sciences 5:1315-1324.

Kung, L. Jr., Shaver, R.D., Grant, R.J. and Schmidt, R.J. 2018. Silage review: Interpretation of chemical, microbial, and organoleptic components of silages. Journal of Dairy Science 101:4020-4033.

López-Sandin, I., Gutiérrez-Díez, A., Medina-Herrera, N., Gutiérrez-Castorena, E., and Zavala-García, F. 2019. Evaluation of the use of energy in the production of sweet sorghum (Sorghum bicolor (L.) Moench) under different production systems. Energies 12:1-13.

Lu, X., and Shen, Y. 2011. Effect of organic fertilizer application on yield and quality in sweet Sorghum. Acta Agrestia Sinica 19:269-272.

Mahfouz, H., Ali, A.M.M., Megawer, E.L., and Mahmoud, A.S. 2015. Response of growth parameters, forage quality and yield of dual-purpose sorghum to re-growth and different levels of FYM and N fertilizers in new reclaimed soil. International Journal of Current Microbiology and Applied Sciences 4:762-782. 
McDonald, P., Henderson, A.R., and Heron, S.J. 1991. The biochemistry of silage. $2^{\text {nd }}$ ed. Chalcombe Publications, Marlow, UK.

Mertens, D.R. 2002. Gravimetric determination of amylase-treated neutral detergent fiber in feeds with refluxing in beakers or crucibles: Collaborative study. Journal of AOAC International 85:1217-1240.

Moura, M.M.A., Pires, D.A.A., Costa, R.F., Tolentino, D.C., Rigueira, J.P.S., and Sales, E.C.J. 2017. Nutritional value of sorghum silages. Acta Scientiarum. Animal Sciences 39:137-142.

Newman, Y., Erickson, J., Vermerris, W., and Wright, D. 2013. Forage sorghum (Sorghum bicolor): Overview and management. No.SS-AGR-333. IFAS Extension, University of Florida, Gainesville, Florida, USA.

Penn, C.J., Vitale, J., Fine, S.T., Godsey, C.B., and Payne, J. 2014. Sweet sorghum as biofuel feedstock: Nutrient source, yield, soil quality, economics, and manure transportation. Agronomy Journal 106:1722-1734.

Poblete-Grant, P., Suazo-Hernández, J., Condron, L., Rumpel, C., Demanet, R., Malone, S.L., et al. 2020. Soil available P, soil organic carbon and aggregation as affected by long-term poultry manure application to Andisols under pastures in Southern Chile. Geoderma Regional 21:e007271.

Rani, B., Nirali, B., Zalawadia, N.M., and Rushang, K. 2019. Effect of different levels of chemical and nano nitrogenous fertilizers on yield and yield attributes of sorghum crop (Sorghum bicolor L.) cv. Gundri. International Journal of Current Microbiology and Applied Sciences 8:2878-2884.

Ritz, C.W., and Merka, W.C. 2009. Maximizing poultry manure use through nutrient management planning. UGA Extension Bulletin 1245. University of Georgia, Athens, Georgia, USA. Available at https://secure.caes.uga.edu/extension/publications/ files/pdf/B1245_3.PDF (accessed 02 March 2020).

Roby, M.C., Fernandez, M.G.S., Heaton, E.A., Miguez, F.E., and VanLoocke, A. 2017. Biomass sorghum and maize have similar water-use-efficiency under non-drought conditions in the rain-fed Midwest U.S. Agricultural and Forest Meteorology 247:434-444.

Saini, A.K. 2012. Forage quality of sorghum (Sorghum bicolor) as influenced by irrigation, nitrogen levels and harvesting stage. Indian Journal of Scientific Research 3:67-72.

Santos, R.D., Pereira, L.G.R., Neves, A.L.A., Rodrigues, J.A.S., Costa, C.T.F., and Oliveira, G.F. 2013. Agronomic characteristics of forage sorghum cultivars for silage production in the lower middle San Francisco Valley. Acta Scientiarum. Animal Sciences 35:13-19.

Simioni, T.A., Hoffmann, A., Gomes, F.J., Mousquer, C.J., Teixeira, U.H.G., Fernandes, G.A., et al. 2014. Senescência, remoção, translocação de nutrientes e valor nutritivo em gramíneas tropicais. PUBVET 8(13):1743.

Wen, Z., Shen, J., Blackwell, M., Li, H., Zhao, B., and Yuan, H. 2016. Combined applications of nitrogen and phosphorus fertilizers with manure increase maize yield and nutrient uptake via stimulating root growth in a long-term experiment. Pedosphere 26:62-73.

Zanine, A.M., Santos, E.M., Ferreira, D.J., Oliveira, J.S., Almeida, J.C.C., and Pereira, O.G. 2010. Evaluation of elephant grass silage with the addition of cassava scrapings. Revista Brasileira de Zootecnia 39:2611-2616. 